\section{Crystalline Cstrone isolated from Urine of the Laying Hen}

Althougr cestriol, œstrone and œstradiol have been detected in mixed avian excreta ${ }^{1}$ and in extracts of ovaries of laying hens ${ }^{2}$ by chromatographic methods, it would appear that only cestradiol-17 $\beta$ has been isolated hitherto from avian material in crystalline form and identified by infra-red spectrophotometry $^{3}$. We have now secured similar evidence for the presence of ostrone in avian urine.

Approximately $30 \mathrm{l}$. urine (equivalent to $128 \mathrm{bird}$ days) was obtained from a laying hen furnished with exteriorized urethral orifices by the method of Dixon and Wilkinson. Estrogen extracts of the acidhydrolysed urine were prepared by the method of Bauld and Greenway ${ }^{5}$, and the lipophilic fraction was chromatographed on paper in a chloroform-formamide system $^{6}$. The presumptive cestrone zones were cut out and eluted with methanol/dichloromethane $(1: 1 \mathrm{v} / \mathrm{v}$ ). The solvent was removed and the residue dissolved in a mixture of benzene and carbon tetrachloride ( $1: 2$ by vol.) and purified by passage through a column of Woelm alumina as described by Ittrich? After removal of the solvent the residue was crystallized twice from aqueous ethanol. The final yield was approximately $0.25 \mathrm{mgm}$.

The sample was dissolved in acetone and the solution evaporated on powdered potassium bromide, which was then ground by hand and pressed into a disk. A sample of reference cestrone (Steroid Laboratories, Montreal) was similarly prepared. Spectrophotometry was performed with a Perkin-Elmer model 21 spectrophotometer fitted with a sodium chloride prism.

The infra-red absorption spectra of the presumptive oestrone from hen's urine and of the reference oestrone are shown in Fig. 1. There were differences in the region of - $\mathrm{OH}$ stretching bands, but these were probably a consequence of differences in crystallinity or water absorptivity as between the samples. There was excellent agreement between the two spectra for all points below $2,000 \mathrm{~cm} .^{-1}$. Accordingly, it can be concluded that the crystalline material isolated from hen's urine was identical with the reference oestrone.

This work was supported by a grant-in-aid of research (No. BT-56) from the National Research Council of Canada.

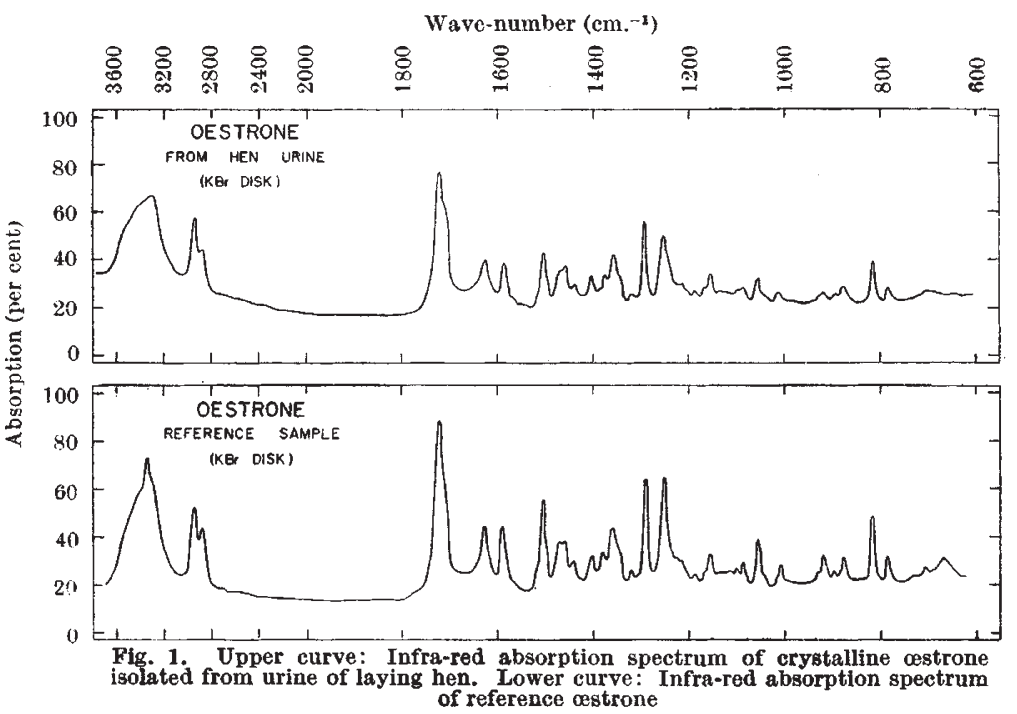

We thank Dr. R. Norman Jones and Mr. R. Lauzon, National Research Council of Canada, Ottawa, for determining the infra-red absorption spectra on which the identification of the crystalline ostrone from hen's urine was based.

\section{AINSWORTh}

R. H. Сомmon

Department of Agricultural Chemistry, Macdonald College,
McGill University,
P.Q.

${ }^{1}$ Hurst, R. O., Kuksis, A., and Bendell, J. F., Canad. J. Biochem. Physiol., 35, 637 (1957).

${ }^{2}$ Layne, D. S., Common, R. H., Maw, W. A., and Fraps, R. M., Nature, 181, 351 (1958).

${ }^{3}$ MacRae, H. F., Layne, D. S., and Common, R. H., Poultry Sci., 38,684 (1959).

'Dixon, J.' M., and Wilkinson, W. S., Amer. J. Vet. Res., 18, 665 (1957).

5 ]3auld, W. S., and Greenway, R.M., Methods of Biochemical Analysis, 5, 392, edit. by Glick, D. (Interscience Pub., Inc., New York, 1957.).

- Layne, D. S., and Marrian, G. F., Biochem. J., 70, 244 (1958).

'Ittrich, G., Hoppe-Seyler's Z. Physiol. Chemie, 312, 1 (1958).

\section{Effects of Administration of Oxytocin and Prolactin on Nucleic Acids and Phosphoprotein Contents of Mammary Glands in Lactating Rats}

Benson and Folley ${ }^{1}$ have demonstrated from the histological point of view that the injection of oxytocin as well as prolactin into lactating rats after removal of their litters showed a marked retarding effect on the involution of mammary gland tissue, and this finding was confirmed by $u^{2}$ and others, ${ }^{3,4}$. In previous experiments ${ }^{2,5}$, however, we failed to see the effects on the in vitro respiratory activity of the mammary gland tissue.

Contents of deoxyribonucleic acid (DNA) of the mammary gland under various conditions have been estimated by many workers ${ }^{6-9}$, and are considered as an indicator of the quantity of parenchymal tissue in the gland. Amounts of ribonucleic acid (RNA) and RNA : DNA ratio in the lactating mammary gland appear to be closely related to the rate of milkprotein synthesis taking place in the gland. In addition to these, amounts of phosphoprotein contained in the gland can be regarded as a conventional scale of millk accumulation in the gland ${ }^{2}$, since phosphoprotein found in the gland is mainly derived from casein.

It was considered of interest, therefore, to reinvestigate the problem by using the determinations of nucleic acids and phosphoprotein in the gland.

Thirty-nine Wistar strain female rats in first lactation, weighing 170 220 gm., were used. Litters were reduced to six on the first day of lactation, three of each sex being kept whenever possible. They were weaned at the stage of full lactation (on eleventh-thirteenth day of lactation). Hormonal treatment was started from the afternoon of the weaning day and continued for 3 days. Oxytocin ('Syntocinon', Sandoz, Ltd., Basle; 1.0 and 2.0 I.U. in $0.5 \mathrm{ml}$. of 